\title{
Antioxidants as a defence against reactive oxygen species
}

\section{Antyoksydanty jako obrona przed reaktyunymi formami tlenu}

\begin{abstract}
Reactive oxygen species are formed as a natural product of metabolic processes occurring in the organism or under the influence of external factors. Under homeostasis, they play an important role as a cellular signaling device. During oxidative stress, when they are produced in excess, they can cause damages to proteins, lipids, carbohydrates or nucleic acids. Exposure of cells and extracellular structures to free radicals activate natural mechanisms to eliminate free radicals and their derivatives.

The aim of the article was to present what antioxidants are, and how they protect cells against the free radicals.

The protective system against the free radicals consists of antioxidant enzymes: superoxide dismutase, catalase, glutathione peroxidases, and reductase. Low-molecular antioxidants such as vitamin C, E, carotenoids, coenzyme $\mathrm{Q}_{10}$, flavonoids, glutathione and melatonin also play an important role.
\end{abstract}

Keywords: antioxidants, free radicals, antioxidant enzymes, non-enzymatic antioxidants

\section{STRESZCZENIE}

Reaktywne formy tlenu powstają jako naturalny produkt procesów metabolicznych zachodzących w organizmie lub pod wpływem czynników zewnętrznych. W warunkach homeostazy ustroju pełnią ważną rolę jako sygnalizatory komórkowe. Wytworzone w nadmiarze, w czasie stresu oksydacyjnego, mogą powodować uszkodzenia w obrębie białek, lipidów, węglowodanów czy kwasów nukleinowych. Ekspozycja komórek oraz struktur pozakomórkowych na działanie wolnych rodników powoduje aktywację naturalnych mechanizmów, mających na celu eliminowanie wolnych rodników i ich pochodnych.

Celem artykułu było przedstawienie roli antyoksydantów w procesie ochrony komórek przed działaniem wolnych rodników.

System ochronny przed wolnymi rodnikami stanowią enzymy antyoksydacyjne: dysmutazy ponadtlenkowe, katalaza, peroksydazy glutationowe oraz reduktaza glutationowa. Ważną rolę pełnią również przeciwutleniacze niskocząsteczkowe, takie jak: witamina C, E, karotenoidy, koenzym $\mathrm{Q}_{10}$, flawonoidy, glutation czy melatonina.

Słowa kluczowe: antyoksydanty, wolne rodniki, enzymy antyoksydacyjne, przeciwutleniacze nieenzymatyczne

\section{INTRODUCTION}

Oxygen makes life possible on Earth. It takes part in metabolic processes and enzymatic reactions, as a result of which it is converted into free radicals. An oxygen molecule can undergo two- or one-electron reduction to a water molecule. By means of these processes, reactive oxygen species (ROS) are formed, which, apart from free radicals, are also singlet oxygen and hydrogen peroxide. As you know, ROS are extremely reactive, they act fast and non-specific. They have the ability to enter into chemical reactions with cell components such as proteins, lipids and DNA deoxyribonucleic acid, thus depriving them of their biological function. 


\section{SOURCES OF ROS}

Free radicals can be created in the body as a result of external factors, such as poor diet, smoking or alcohol consumption. An additional source of excessive free radicals may be environmental and industrial pollution, ionizing radiation and an increased rate of breathing during physical exertion. However, due to the continuity of the process, the intracellular generation of free radicals, related to the metabolic reactions in the body, such as oxygen respiration or inflammatory processes, is the most important [1]. The main source of the formation of ROS in the body is the mitochondrial respiratory chain. This chain consists of four lipoprotein complexes between which electrons are transferred. Electron transport is provided by transporters such as coenzyme Q10 (linking complexes I and II) and cytochrome c (linking complexes III and IV). The two-electron reduction reactions of the oxygen molecule are associated with the transfer of an even amount of hydrogen or electrons to the oxygen being the substrate of complex IV. It is estimated that about $2-5 \%$ of the electrons transferred by the complexes may leave the respiratory chain and enter into one-electron reactions with oxygen, which in turn leads to the formation of oxygen free radicals [2]. The attachment of an electron to an oxygen molecule leads to the formation of a superoxide radical $\left(\mathrm{O}_{2}{ }^{-}\right)$. The superoxide anion radical after attaching a second electron can be transformed into other forms of ROS, a non-radical product, but very reactive hydrogen peroxide $\left(\mathrm{H}_{2} \mathrm{O}_{2}\right)$. The addition of the third electron generates a highly reactive hydroxyl radical (HO), which has the ability to react with practically all biologically important compounds present in the body [3].

The sources of ROS in mitochondria may also be the reactions of the enzyme monoamine oxidase and $\alpha$-ketoglutarate dehydrogenase. Many radicals are also formed as a result of natural detoxification processes of the organism, e.g. in the metabolism of xenobiotics. Endogenous sources of free radicals are also lung vascular endothelial cells, eosinophils, neutrophils, as well as monocytes and macrophages $[2,3]$.

\section{THE MEANING OF ROS IN PHYSIOLOGY}

Radicals are present in every living cell, and their concentration in tissues varies widely as a result of the action of numerous chemical compounds, radiation, diseases, stress or the aging of the organism. The multidirectional nature of radicals' activity has been revealed, which depends on their concentration in the cell.

It is known that low concentrations of ROS are necessary for many processes in the body and can perform many beneficial functions, while higher concentrations can be harmful and irreversibly damage both the cell structure and the body's tissues, reacting with biologically important macromolecules. Exceeding certain concentrations of free radi- cals in cells and chronic exposure to them lead to oxidative stress [8]. The consequences of oxidative stress are damage to the mitochondria, lipid peroxidation, damage within the cell membrane and its receptors, and damage to nuclear and mitochondrial DNA [1].

It has been proven that ROS act as mediators and regulators of cellular metabolism, influence the transmission of signals to cells and within cells, and stimulate the transport of glucose to cells, as well as serotonin to thrombocytes [4]. Their role in the regulation of gene expression and activation of proteins responsible for cell division is emphasized.

The participation of ROS in the body's immune processes has been demonstrated in many studies. It is worth paying attention to the phenomenon of "oxygen burst" used by granulocytes or monocytes to eliminate pathogens [6]. By increasing the permeability of the capillary walls, ROS are responsible for the proper course of the inflammatory reaction in the body. They take part in excretion drugs from the body, muscle contractions, secretion of hormones and in the regulation of vascular tone [5]. Under physiological conditions, they also take part in the formation of high-energy phosphorus compounds, detoxification of xenobiotics, and in ovulation. They also play an important role in the aging process - they decide about the death or survival of cells. It should be noted that low concentrations of ROS induce cell differentiation processes, while higher concentrations direct the cell to apoptosis. As a result, damaged cells are eliminated and do not pose a threat to the body [7].

\section{ANTIOXIDATIVE DEFENCE MECHANISMS}

The harmful effects of ROS in the body are counterbalanced by compounds called antioxidants. These are substances which aim is to prevent oxidation of molecules and converting free radicals into inactive forms, thus reducing the number of cell damage resulting from excessive concentration of ROS in the body [9]. Defence mechanisms are triggered in the place where the concentration of ROS is higher than it should be. The type of antioxidant used in the reaction with the radical or other ROS depends on the type of the substrate, the place of its formation and the structure it attacks [4].

There is a certain group of factors and defence mechanisms that are part of the antioxidant defence system (ADS). Due to the mechanism of action, antioxidants are divided into enzymatic and non-enzymatic, while non-enzymatic antioxidants include compounds of both endogenous and exogenous origin. They constitute three lines of cell defence against ROS [9]. The first line of ADS prevents the production of free radicals, including superoxide dismutase, catalase and glutathione peroxidase. Repair mechanisms, or the second line of defence, are designed to break free radical chain reactions, such as vitamin $\mathrm{A}, \mathrm{C}$ and $\mathrm{E}$, bilirubin, glutathione, uric acid, carnitine and flavonoids. On the oth- 
er hand, the third line of defence consists of mechanisms that repair or eliminate cells damaged by ROS [10].

\section{ANTIOXIDANT ENZYMES}

Among the compounds with antioxidant activity, the main role is played by endogenous antioxidants, mostly enzymes. The main enzymatic components of the antioxidant system are: superoxide dismutase (SOD), catalase (CAT), glutathione peroxidase (GPx) and glutathione reductase (GR) $[11,12]$.

The primary antioxidant enzyme is superoxide dismutase, which stops the chain reaction of free radical damage. It converts the more toxic superoxide anion radical into less toxic hydrogen peroxide, which is then broken down by catalase and peroxidase [10,13].

Depending on the place of occurrence in the body of mammals, three isoforms of the enzyme superoxide dismutase are distinguished [14-16]:

- Cu-ZnSOD (SOD1) - zinc-copper superoxide dismutase, found mainly in the cytosol of the liver, testes and kidneys cells, as well as in erythrocytes and cells of the central nervous system. Its presence has also been found in such organelles as the cell nucleus, lysosomes and peroxisomes. SOD1 is a protein that shows resistance to high temperature and to the action of proteolytic enzymes;

- Mn-SOD (SOD2) - manganese superoxide dismutase occurs mainly in the mitochondria, although low amounts have also been found in extracellular spaces and peroxisomes. As a result of oxidative stress, as well as under the influence of TNF- $\alpha$, IL-1 or liposaccharides, the activity of the SOD2 enzyme increases. In turn, high pH leads to its reduction;

- EC-SOD (SOD3) - extracellular superoxide dismutase is an isoenzyme of dismutase found in tissues, blood plasma and body fluids such as lymph, synovial fluid, interstitial and cerebrospinal fluid. In tissues, it occurs mainly in the extracellular matrix and on the surface of cells, where it is present at a concentration 20 times higher than in plasma. Tissue EC-SOD accounts for 90-99\% of the body's EC-SOD, and approximately $1 \%$ of EC-SOD is in the vascular system, in the balance between plasma and endothelium. There is also a large amount of this enzyme in the blood vessels, lungs and placenta. Its lower amounts have been found in skeletal muscles, liver, brain and kidney. Like zinc-copper dismutase, EC-SOD is thermostable and resistant to high urea concentrations and high $\mathrm{pH}$. It prevents the harmful effects of superoxide anion radical in intercellular spaces and in blood vessels, where it is the most important antioxidant enzyme. The activity of the EC-dismutase of the blood vessel wall is much greater than the activity of this enzyme in the parenchymal organs. EC-SOD, similarly to $\mathrm{Cu}-\mathrm{ZnSOD}$, shows peroxidase activity, inactivating $\mathrm{H}_{2} \mathrm{O}_{2}$.
All isoforms of superoxide dismutase belong to the group of metalloenzymes and catalyze the dismutation of the superoxide anion radical to hydrogen peroxide and water. This reaction takes place in two stages and is illustrated by the equations [14]:

$$
\begin{gathered}
\text { SOD }-\mathrm{Me}^{\mathrm{n}}+\mathrm{O}_{2}{ }^{--} \text {SOD }-\mathrm{Me}^{\mathrm{n}-1}+\mathrm{O}_{2} \\
\text { SOD- } \mathrm{Me}^{\mathrm{n}-1}+\mathrm{O}_{2}{ }^{--}+2 \mathrm{H}^{+} \text {SOD-Me }-\mathrm{Me}_{2} \mathrm{O}_{2}
\end{gathered}
$$

Catalase is an enzyme that belongs to the class of oxidoreductases. Catalase occurs in the peroxisomes, mitochondria and the endoplasmic reticulum. High activity of this enzyme has also been demonstrated in the cytosol of liver and kidney cells, in erythrocytes, bone marrow and mucous membranes. Catalase is an enzyme with dual activity. Depending on the concentration of $\mathrm{H}_{2} \mathrm{O}_{2}$ in the cell, it can exhibit catalase or peroxidase activity. When the concentration of hydrogen peroxide is high, catalase removes it, converting into water and oxygen. On the other hand, when the concentration of $\mathrm{H}_{2} \mathrm{O}_{2}$ is low, catalase shows a peroxidase ability and in the presence of an appropriate donor like ethanol, methanol, formate, nitrites, quinones, it removes hydrogen peroxide, by oxidizing these compounds [17].

The primary function of the catalase enzyme in cells is to participate in the hydrogen peroxide disproportionation reaction. This reaction takes place in two stages. At first, hydrogen peroxide is reduced to water with the participation of iron $\mathrm{Fe}^{3+}$ ions of the heme system. At this point the I - Fe (V) - CAT compound is formed. The second stage is the oxidation of another molecule of hydrogen peroxide by compound I, resulting in the formation of molecular oxygen and water [17].

$$
\begin{gathered}
\mathrm{H}_{2} \mathrm{O}_{2}+\mathrm{Fe}(\mathrm{III})-\mathrm{CAT} 2 \mathrm{H}_{2} \mathrm{O}+\mathrm{O}+\mathrm{Fe}(\mathrm{V})-\mathrm{CAT} \\
\mathrm{H}_{2} \mathrm{O}_{2}+\mathrm{O}=\mathrm{Fe}(\mathrm{V})-\mathrm{CAT} \mathrm{Fe}(\mathrm{III})-\mathrm{CAT}+\mathrm{H}_{2} \mathrm{O}+\mathrm{O}_{2}
\end{gathered}
$$

Catalase, interacting with peroxidase and glutathione reductase, plays an important role in protecting red blood cells from the effects of oxidative stress, as they are exposed to high concentrations of oxygen. One molecule of catalase per minute can convert about 6 million molecules of hydrogen peroxide to water and oxygen. An additional advantage of this enzyme is its activity in a wide $\mathrm{pH}$ range (5.0-10.5) [17].

The next elements of the antioxidant enzyme system are glutathione peroxidases (GPx). These enzymes contain selenium in the active site, which is in the form of selenocysteine. For this reason, glutathione peroxidases are also called selenoperoxidases. Glutathione peroxidase is located mainly in the cytosol, but also in the mitochondria and in the cell nucleus. Due to the detoxification processes that take place in the liver, the activity of this enzyme is the highest there, as well as in the blood and lungs. At least four isoforms of GPx are currently known, which differ in their location and subunit structure [18]:

- cGPx - classic, cytosolic glutathione peroxidase, its main function is to reduce hydrogen peroxide and organic hydroperoxides, excluding lipid hydroperoxides, 
- PH-GPx - glutathione peroxidase of lipid hydroperoxides, capable of reducing phospholipid hydroperoxides, occurs in the cytosol and is partially associated with cell membranes,

- eGPx - glutathione peroxidase, also known as extracellular peroxidase, located in the serum, has the ability to catalyze lipid hydroperoxides and hydrogen peroxide,

- GI-GPx - gastrointestinal peroxidase, reduces hydrogen peroxide and organic peroxides, but does not reduce phospholipid hydroperoxides.

Glutathione peroxidase plays a special role in mitochondria, where the catalase enzyme is missing, as it is involved in the removal of harmful hydrogen peroxide [18].

The best-known form of GPx is the classical form (cGPx), which also occurs in red blood cells. The main function of this enzyme is to protect cells against oxidative stress and to neutralize hydrogen peroxide and organic peroxides $(\mathrm{LOOH})$ in intra- and extracellular reactions in the presence of the reduced form of GSH glutathione [13]. The end product of the reaction of glutathione with hydrogen peroxide is glutathione disulfide (GSSG), which is a harmful compound. To counteract the accumulation of GSSG in the cell, glutathione peroxidase is related to glutathione reductase (GSHR), which in turn is able to restore the reduced form of glutathione at the expense of NADPH oxidation [7].

$$
\begin{gathered}
2 \mathrm{GSH}+\mathrm{H}_{2} \mathrm{O}_{2} \underset{\text { GSH-Px }}{\longrightarrow} \mathrm{GSSG}+2 \mathrm{H}_{2} \mathrm{O} \\
\mathrm{GSSG}+\mathrm{NADPH}+\mathrm{H}^{+} \underset{\text { GSSG reductase }}{\longrightarrow} 2 \mathrm{GSH}+\mathrm{NADP}^{+} \\
\mathrm{H}_{2} \mathrm{O}_{2}+\mathrm{NADPH}+\mathrm{H}^{+} \rightarrow 2 \mathrm{H}_{2} \mathrm{O}+\mathrm{NADP}^{+}
\end{gathered}
$$

Glutathione reductase (GR) is a flavoenzyme belonging to the oxidoreductase. Its main goal is to maintain an appropriate level of reduced glutathione (GSH) in cells, thanks to the ability to convert the non-reduced form of glutathione (GSSG) into GSH. It also catalyzes the reactions of mutual transformations of sulfhydryl groups and disulfides, for which it uses NADPH as a reducing agent $[18,19]$.

$$
\text { GSSG + NADPH } \rightarrow 2 \text { GSH + NADP }
$$

\section{NON-ENZYMATIC ANTIOXIDANTS}

Removal of free radicals through the action of highly specialized enzymatic systems is supported by the participation of non-enzymatic antioxidants [20]. They are protective substances that donate their electrons to free radicals, and as a result they lose the ability to oxidize other components. Otherwise, antioxidants are called free radical scavengers and protect cells against free radical reactions. Among them, there are exogenous (water and fat-soluble) and endogenous compounds [9].

The group of exogenous antioxidants includes:

- ascorbic acid (vitamin C) - dissolves well in water, a high content of this vitamin is present in citrus fruits, rosehips, black currants, grapes, and also in tomatoes. Vitamin $\mathrm{C}$ is one of the strongest antioxidants. It prevents oxidative processes caused by the action of free radicals. It is most effective against radicals such as $\mathrm{O}_{2}, \mathrm{O}_{2}{ }^{-}$and ${ }^{\circ} \mathrm{OH}$ [21];

- $\alpha$-tocopherol (vitamin E) - fat-soluble, protects cell membranes, lipids and lipoproteins against oxidation and maintains an appropriate oxy-reduction potential. Its role is to scavenge organic free radicals and quench singlet oxygen [20];

- vitamin and provitamin A ( $\beta$-carotene) - $\beta$-carotene and other carotenoids have the ability to extinguish the action of free radicals by transferring electrons or creating adducts with them, they also have anti-cancer and anti-aging properties. $\beta$-carotene shows the ability to remove singlet oxygen and lipid peroxides [1, 22];

- flavonoids and anthocyanins - occur in plants such as: mountain arnica, chamomile, liquorice, ginkgo, hops, green and black tea, they have the ability to scavenge free radicals, protect against lipid oxidation and have anti-inflammatory and antimutagenic properties [23];

- coenzyme Q10 - is a fat-soluble antioxidant, binds free radicals and inhibits lipid peroxidation processes and prevents oxidative modifications of DNA and proteins. Moreover, it has the ability to regenerate vitamin E [24];

- glutathione - a water-soluble cysteine-containing tripeptide commonly found in all plant and animal eukaryotic cells. It is highly concentrated in the liver. It can be in reduced (GSH) and oxidized (GSSG) forms. There are three main reservoirs of GSH in eukaryotic cells. Almost 90\% of cellular GSH is found in the cytosol, $10 \%$ in the mitochondria and a low percentage in the endoplasmic reticulum [25]. Glutathione is a multifunctional molecule which influences many processes taking place in cells. It is one of the most important elements of the antioxidant system of cell defence. Its presence is necessary to maintain the redox balance and counteract the effects of oxidative stress. It has the ability to reduce hydrogen peroxide and maintains the appropriate level of thiol groups in proteins (-SH) in a reduced form. GSH also has the ability to react directly with the superoxide anion radical and the hydroxyl radical. Moreover, it is involved in the detoxification of xenobiotics and their metabolites, as well as pesticides and heavy metal ions $[18,26]$.

\section{OTHER ANTIOXIDANTS}

- Melatonin. It is a hormone produced by the pineal gland. In low concentrations, it dissolves in both water and fats, therefore it can act as a hydrophilic and hydrophobic antioxidant. This hormone was found to be a more effective radical scavenger than vitamin $\mathrm{E}$ and glutathione [27]. In combination with other antioxidants, its antioxidant effect is stronger, which indicates the synergy of antioxidant interaction. Vitamin $\mathrm{C}$ has been proven to contribute to the regeneration of the pineal hormone. The functions performed by melatonin are primarily the protection of 
cell nuclei containing DNA structures [9]. Moreover, experiments have shown that melatonin inhibits the processes of lipid, protein and DNA oxidation, and also mediates the stimulation of the antioxidant activity of enzymes [20].

- $\alpha$-lipoic acid (LA). It is an eight-carbon saturated fatty acid in which two sulfur atoms are bonded to carbon atoms 6th, 7th and 8th to form a dithiol ring. As a result of the reduction of this ring, a reduced form is obtained dihydrolipoic acid (DHLA). The presence of a non-polar aliphatic chain determines the good solubility of LA and DHLA in organic solvents. On the other hand, the moderate length of this chain and the presence of the carboxyl group mean that these compounds also show limited solubility in water [28]. In addition to de novo synthesis, food is the second source of lipoic acid in mammalian cells. The highest amounts of lipoic acid are found in offal, spinach, broccoli, tomatoes, brussels sprouts and fruits [29]. $\alpha$-lipoic acid and dihydrolipoic acid show a strong antioxidant effect and act as free radical scavengers. LA reacts with singlet oxygen $\left({ }^{1} \mathrm{O}_{2}\right)$, hydroxyl radical $(\mathrm{HO} \cdot)$, hypochlorous acid $(\mathrm{HOCl})$ and peroxynitrite $\left(\mathrm{ONOO}^{-}\right)$. It is not capable of scavenging superoxide radical anion $\left(\mathrm{O}_{2}{ }^{--}\right)$ and hydrogen peroxide $\left(\mathrm{H}_{2} \mathrm{O}_{2}\right)$. Dihydrolipoic acid neutralizes the superoxide radical $\left(\mathrm{O}_{2}^{--}\right)$, hypochlorous acid $(\mathrm{HOCl})$ and peroxyl radicals (LOO*). In addition, it also effectively neutralizes hydroxyl radicals (HO'). It is not capable of scavenging singlet oxygen species and, similarly to lipoic acid, hydrogen peroxide $\left(\mathrm{H}_{2} \mathrm{O}_{2}\right)$. Some LA metabolites also have the ability to scavenge free radicals: bisnorliponate and tetranorliponate [29, 30]. By reacting with radical and non-radical ROS, $\alpha$-lipoic acid is transformed into the radical cation of lipoic acid (LA), which is illustrated by the equation:

$$
\mathrm{LA}+\mathrm{OH}^{\cdot} \rightarrow \mathrm{LA}^{+\cdot}+\mathrm{OH}^{-}
$$

- Cation-radical $\mathrm{LA}^{+*}$ is much less reactive than, for example, the hydroxyl radical, but still poses a threat to the cell. However, it is easily converted into LA with the participation of other intracellular antioxidants that can be regenerated by DHLA [28, 30].

- Dihydrolipoic acid (DHLA) is a strong reducer (more active than LA), thanks to which it has the ability to regenerate the reduced forms of vitamin $\mathrm{C}$ and $\mathrm{E}$ and prolongs their effectiveness. In addition, it has a greater ability to regenerate vitamin $\mathrm{C}$ than the reduced form of glutathione. DHLA can also reduce the oxidized forms of coenzyme Q10. In turn, $\alpha$-lipoic acid directly extends the life of vitamin C, glutathione and coenzyme Q10, and indirectly of vitamin E [29].

The prevention of antioxidant stress by $\alpha$-lipoic acid and dihydrolipoic acid is also associated with the ability to chelate metal ions. Iron, copper or cobalt ions in a form not bound to proteins can generate free radicals, e.g. a hydroxyl radical. LA and DHLA acid form stable complex compounds in solutions with transition metal ions and thus eliminate them from the environment. LA binds copper, cadmium, zinc and lead cations, while DHLA binds $\mathrm{Cu}^{2+}, \mathrm{Zn}^{2+}, \mathrm{Pb}^{2+}$, $\mathrm{Hg}^{2+}$ ions, and reduces $\mathrm{Fe}^{3+}$ to $\mathrm{Fe}^{2+}[29]$.

\section{NATURAL SOURCES OF ANTIOXIDANTS}

Slowing down the aging process is possible due to a diet rich in ingredients with antioxidant properties. Apart from the anti-aging effect, such a diet plays an important role in the prevention of diseases including diabetes, atherosclerosis, Alzheimer's or Parkinson's disease. Nowadays, there are many factors that contribute to increased production of free radicals like air pollution, sitting lifestyle or eating meals "on the run". As prevention of development of diseases related to the accumulation of free radicals, a diet rich in vitamin $\mathrm{E}$, vitamin $\mathrm{C}$, zinc, magnesium and selenium is recommended. Recent studies indicate that vegetables and fruits, apart from the above-mentioned antioxidants, also contain other substances with antioxidant activity, such as flavonoids and other phenolic compounds [31].

Fruits are a rich source of substances with antioxidant properties. Many polyphenols and anthocyanins are present in the fruits of chokeberry and blueberry. Also, apples, cherries, strawberries, blackberries, elderberries, rosehips and cranberries are a source of many valuable biologically active substances. Vegetables are also characterized by the ability to bind free radicals, but have weaker antioxidant properties than fruit. Particularly noteworthy are: garlic, kale, spinach, broccoli and beetroot, which are a good sources of quercetin. Tomatoes are valued for their high content of lycopene, which is also a compound with strong antioxidant properties [32].

The antioxidants present in fruits and vegetables have health-promoting properties. It is recommended to increase their supply in the daily diet in order to increase the body's antioxidant potential. However, it should be remembered that additional antioxidant supplementation may lead to the disturbance of pro-oxidative and antioxidant homeostasis. As a result, the activity of antioxidant enzymes is reduced and, at the same time, the body's resistance to free radicals is decreased. This, in turn, may accelerate the aging processes and the development of many diseases related to oxidative stress [33].

\section{SUMMARY}

The described enzymes and non-enzymatic antioxidants play an important role in protecting the body's cells against reactive oxygen species. As components of the antioxidant defence system, they protect against the harmful effects of free radicals generated in processes such as inflammation or ischemia. Moreover, they maintain the pro-and antioxidant balance at the time of increased concentration of free 
radicals. Antioxidant vitamins have the ability to neutralize accumulated ROS, and also increase the defence capabilities of other endogenous antioxidants. For preventive purposes, supplementation with exogenous antioxidants is of great importance, in particular through the use of a diet rich in natural sources of these substances.

\section{REFERENCES / LITERATURA}

1. Czajka A. Wolne rodniki tlenowe a mechanizmy obronne organizmu. Now Lek. 2006;75(6):582-586.

2. Potargowicz E, Szerszenowicz E, Staniszewska M, Nowak D. Mitochondria jako źródło reaktywnych form tlenu. Postępy Hig Med Dosw. 2005;59:259-266.

3. Piotrowska A, Bartnik E. Rola reaktywnych form tlenu i mitochondriów w starzeniu. Postępy Biochem. 2014;60(2): 240-247.

4. Łuszczewski A, Matyska-Piekarska E, et al. Reaktywne formy tlenu - znaczenie w fizjologii i stanach patologii organizmu. Reumatologia. 2007;45(5):284-289.

5. Jopkiewicz S. Stres oksydacyjny Część I. Stres oksydacyjny jako czynnik rozwoju chorób cywilizacyjnych. Med Środowiskowa. 2018;21(2):48-52.

6. Skiba M, Pedrycz A, Cichacz B. Reaktywne rodniki tlenowe - skuteczność antyoksydantów w terapii. J Polish Hyperb Med Technol Soc. 2016;54(1):41-48

7. Zabłocka A, Janusz M. Dwa oblicza wolnych rodników tlenowych. Postepy Hig Med Dosw. 2008;62:118-124.

8. Puzanowska-Tarasiewicz H, Starczewska B, Kuźmicka L. Reaktywne formy tlenu. Bromat Chem Toksykol. 2008;41(4):1007-1015.

9. Jopkiewicz S. Stres oksydacyjny Część II. Profilaktyka powstawania uszkodzeń wolnorodnikowych. Med Środowiskowa. 2018;21(2):53-59.

10.Kuzdraliński A. Antyoksydanty. www.e-biotechnologia.pl/Artykuly/ antyoksydanty. Accessed 14.03.2018.

11. Stolarzewicz IA, Ciekot J, Fabiszewska AU, Białecka-Florjańczyk E. Roślinne i mikrobiologiczne źródła przeciwutleniaczy. Postepy Hig Med Dosw. 2013;67:1359-1373.

12. Gałecka E, Jacewicz R, Mrowicka M, Florkowski A. Enzymy antyoksydacyjne - budowa, właściwości, funkcje. Pol Merk Lek. 2008; 25(147):266-268.

13. Sikora N, Znajewska Z, Dąbrowska G. Wybrane mechanizmy obronne organizmów przed stresem oksydacyjnym ze szczególnym uwzględnieniem dysmutaz ponadtlenkowych. Eduk Biol i Środowiskowa. 2017; 4:19-31.

14. Skólmowska M, Kmieć M. Enzymosomy antyoksydacyjne - właściwości i zastosowanie. Postępy Hig Med Dosw. 2011;65:640-644.
15. Wołonciej M, Milewska E, Roszkowska-Jakimiec W. Pierwiastki śladowe jako aktywatory enzymów antyoksydacyjnych. Postępy Hig Med Dosw. 2016;70:1483-1498.

16. Skrzycki M, Czeczot H. Zewnątrzkomórkowa dysmutaza ponadtlenkowa (EC-SOD) - budowa, właściwości i funkcje. Postępy Hig Med Dosw. 2004;58:301-311.

17.Ścibior D, Czeczot H. Katalaza - budowa, właściwości, funkcje. Postęp Hig Med Dosw. 2006;60:170-180.

18. Łukaszewicz-Hussain A. Rola glutationu i enzymów z nim związanych w procesach antyoksydacyjnych organizmu. Med Pr. 2003;54(5):473-479.

19. Deponte M. Glutathione catalysis and the reaction mechanisms of glutathione-dependent enzymes. Biochim Biophys Acta - Gen Subj. 2013;1830(5):3217-3266.

20. Gryszczyńska B, Iskra M. Współdziałanie antyoksydantów egzogennych i endogennych w organizmie człowieka. Now Lek. 2008;77(1):50-55.

21. Rutkowski M, Matuszewski T, Kędziora J, et al. Witaminy E, A i C jako antyoksydanty. Pol Merkur Lek. 2010;29(174):377-381.

22. Kisała J. Antyutleniacze pochodzenia roślinnego i syntetycznego ich rola i właściwości. Zesz Nauk Zaktadu Chem i Toksykol Żywności Uniw Rzesz. 2009;11:109-114.

23. Puzanowska-Tarasiewicz H, Kuźmicka L, Tarasiewicz M. Antyoksydanty a reaktywne formy tlenu. Bromatol i Chem Toksykol. 2010;43(1):9-14.

24. Dominiak K, Jarmuszkiewicz W. Różne oblicza mitochondrialnego koenzymu Q. Postępy Biochem. 2019;65(4):271-277.

25. Lu SC. Regulation of glutathione synthesis. Mol Asp Med. 2009;30(1-2): 42-59.

26. Bukowska B. Funkcje glutationu oraz czynniki zmniejszające jego stężenie. Med Pr. 2005;56(1):69-80.

27. Bartosz G. Druga twarz tlenu. Wolne rodniki w przyrodzie. Warszawa: Wydawnictwo Naukowe PWN; 2003.

28. Malińska D, Winiarska K. Kwas liponowy - charakterystyka i zastosowanie w terapii. Postep Hig Med Dosw. 2005;59:535-543.

29. Huk-Kolega H, Skibska B, Kleniewska P, et al. Rola kwasu liponowego w zdrowiu i chorobie. Pol Merkur Lek. 2011;31(183):183-185.

30. Skorupa A, Michałkiewicz S. Kwas $\alpha$-liponowy - antyutleniacz antyutleniaczy - właściwości i metody oznaczania. Wiadomości Chem. 2017;71:817-842.

31. Sadowska A, Żebrowska-Krasuska M, Świderski F. Przeciwutleniacze w żywności. Postępy Tech Przetwórstwa Spożywczego. 2012;2(1):100-104.

32. Wawrzyniak A, Krotki M, Stoparczyk B. Właściwości antyoksydacyjne owoców i warzyw. Med Rodz. 2011;1:19-23.

33. Michalak A, Krzeszowiak J, Markiewicz-Górka I. Starzenie sie organizmu a stres oksydacyjny oraz zmniejszona sprawność systemów naprawczych. Postęy Hig Med Dosw. 2014;68:1483-1491. 